\title{
Seuranta työkaluna porsastuotannon kehittämisessä
}

\author{
Kati Tuppi ${ }^{1)}$ ja Maija Yliaho ${ }^{2)}$ \\ ${ }^{1)}$ ProAgria Hämeen maaseutukeskus, 13100 Hämeenlinna, kati.tuppi@proagria.fi \\ ${ }^{2)}$ ProAgria Etelä-Pohjanmaan maaseutukeskus, 60220 Seinäjoki, maija.yliaho@proagria.fi
}

\section{Johdanto}

Porsastuotannon seuranta on yksi sikalan toiminnan peruspilareista. Porsastuotannon tunnusluvut antavat sikatalousyrittäjälle käytännönläheistä tietoa toimintansa johtamiseen. Olennaista on tunnistaa tärkeimmät kehittämiskohteet ja löytää niihin tilakohtaisesti soveltuvat ratkaisut.

Sikatilaneuvonnan keskeisenä tehtävänä on vuosittain tuottaa tietoa porsastuotannon tehokkuudesta ja kannattavuudesta (ProAgria Maaseutukeskusten liitto 2003). Sikatilinpäätösohjelma kehitettiin porsastuotannon seurannan rinnalle laskemaan, mitä porsaan tuottaminen tilalle maksaa. Aiemmin sikalan sisäistä tehokkuutta ja kannattavuutta on tuotantomuodosta riippumatta tarkasteltu yhtenä kokonaisuutena. Nyt sikatilinpäätös voidaan laskea erikseen porsastuotantoon, välikasvattamoon, lihasikalaan tai jalostusyksikköön. Sikalan toiminnan tehokkuutta seurataan siis osastoittain kuten mitä tahansa yritystä.

Porsastuotannon tehokkuutta kuvataan usein tunnusluvulla vieroitettu porsaita/emakko/vuosi. Sikatilinpäätöksen tehneiltä tiloilta vieroitettiin v. 2002 keskimäärin 18,9 porsasta emakkoa ja vuotta kohden (taulukko 1). Tilojen välinen vertailu kertoo, missä kohden on onnistuttu ja missä ei. Porsastuotos- ja taloustietojen linkittyminen antaa hyvän työkalun sikalan tehokkuuden analysointiin ja kehittämiskohteiden löytämiseen.

\section{Aineisto ja menetelmät}

Vuoden 2003 alussa Maaseutukeskukset ottivat käyttöön porsaan ja lihasian tuotantokustannusten laskennassa AgroSoftin ${ }^{\circledR} \quad$ WinPig-sikatilinpäätösohjelman. Vuoden 2002 sikatilinpäätökset laskettiin144 sikatilalle. Ensimmäistä kertaa saatiin tietoa yhtäaikaisesti sekä porsastuotannon että talouden tehokkuudesta. WinPig-ohjelmassa voidaan sikatilinpäätös laskea erikseen porsastuotantoon, lihasikalaan tai siitoseläinyksikköön. Näin esimerkiksi yhdistelmäsikala pystyy vertaamaan porsaspuolen tuloksiaan kaikkiin sikatilinpäätöksessä mukana oleviin tiloihin, mikä ennen ei ollut mahdollista. Kaikille yhdistelmäsikaloille lasketaan myös lihasikalan tilinpäätös.

Porsastuotannon tehokkuusluvut laskettiin sikatilinpäätöksessä mukana olleiden tilojen kesken. Tilat ryhmiteltiin vieroitettujen porsaiden $/ \mathrm{em} / \mathrm{v}$ mukaan. Parhaaseen neljännekseen otettiin vieroitettujen porsaiden/em/v mukaan paras $25 \%$ tiloista ja laskettiin niiden keskiarvo. Samoin tehtiin heikoimman neljänneksen suhteen. Porsastuotannon kannattavuuden vertailussa tilat ryhmiteltiin porsaan tuotantokustannuksen mukaan. Tilavertailusta saadaan varmuutta päätöksentekoon sekä löydetään kohde, missä korjaustoimenpiteet näkyvät tuloksessa

\section{Tulosten tarkastelu}

Porsastuotannon tuloksista (taulukko1) korostuu kaksi ydinongelmaa, jotka syövät suomalaisen sikatalouden tehokkuutta - korkea porsaskuolleisuus ja ylimääräiset tehottomuuspäivät. Porsaskuolleisuuden hälytysrajana voidaan pitää tilannetta, kun kaksi porsasta kymmenestä elävänä syntyneestä kuolee. Keinoja porsaskuolleisuuden alentamiseksi löytyy, kunhan tilalla ensin on selvitetty, mihin porsaita kuolee. Nälkä, kylmyys ja karsinan vetoisuus ovat korkeaan porsaskuolleisuuteen altistavia tekijöitä. Kun porsaskuolleisuutta lähdetään järjestelmällisesti alentamaan, vaatii se hoitajalta aikaa ja motivaatiota muuttaa totuttuja toimintatapoja.

Emakko on tehokas silloin, kun se imettää tai on tiineenä. Muuna aikoina kertyy tehottomuuspäiviä, joiden syihin hoitaja voi vaikuttaa. Tehottomuuspäivät pidentävät emakon tuotantokiertoa heikentäen siten koko sikalan tehokkuutta. Eniten tehottomuuspäiviä kertyy ensikoille ja kerran porsineille 
emakoille. Kiimantarkkailuun, tiineytykseen ja tiineyden seurantaan on varattava riittävästi kiireetöntä aikaa. Emakot, jotka toistamiseen uusivat, on karsittava syömästä tuottavien emakoiden katetta. Yrittäjän tulee uskaltaa kyseenalaistaa omia toimintatapoja, kun ratkaisuja ongelmiin haetaan. Parhailla tiloilla uudistus on suunniteltua ja satsaus ensikkoon alkaa jo porsaana. Ruokinnassa ei säästellä, joten ensikko kestää ensimmäisen imetyskauden rasitukset ja jaksaa kasvaa samalla itsekin. Parhaillakin tiloilla tehottomia päiviä kertyy syksyllä enemmän kuin muuna aikana. Silti päiviä kertyy puolitoista viikkoa vähemmän kuin kaikilla tiloilla. Perusasiat ovat kunnossa ruokinta toimii, eläinten terveys on hyvä, olosuhteet kohdallaan ja hoitaja motivoitunut. Tuotannon tehostamiseksi löytyy ratkaisuja, mutta oma toiminta tai tahtotila täytyy ensin ruotia läpi.

Seurantaa käytetään työkaluna myös sikalan toiminnallisessa suunnittelussa. Emakoiden ryhmävieroituksessa tai ryhmittelyssä suunnitellaan tuotantokiertoa pitkälti etukäteen, jolloin sikalan rutiinityöt voidaan rytmittää tehtäväksi tiettynä päivinä. Suunnitelma ei toteudu hetkessä, vaan onnistuakseen vaatii toteuttajaltaan pitkäjänteisyyttä. Palkitsevinta porsastuotoksen nousun lisäksi on työmäärän vähentyminen. Tuotannon seurannan ja toiminnan suunnittelun osuus sikalatyöstä tulee korostumaan lähivuosina entistä enemmän.

Taulukko 1. Porsastuotannon tehokkuuden vertailu sikatilinpäätöksen lasketuilta sikatiloilta (144 sikatilaa). Ryhmittely vieroitettujen porsaiden /emakko/vuosi mukaisesti.

\begin{tabular}{|l|c|c|c|}
\hline & Keskiarvo & Paras 25 \% & Heikoin 25 \% \\
\hline Tuotettu porsaita/em/v., kpl & 18,0 & 20,1 & 14,9 \\
\hline Vier.porsaita/em/v., kpl & 18,9 & 20,9 & 16,0 \\
\hline Pahnueita/em/v., kpl & 2,03 & 2,13 & 30 \\
\hline Ensikkopahnueita,\% & 25 & 21 & 10,5 \\
\hline El.synt/pahnue, kpl & 10,8 & 11,3 & 1,4 \\
\hline Kuoll.synt/pahnue, kpl & 1,3 & 1,2 & 8,8 \\
\hline Vieroitettu/pahnue, kpl & 9,3 & 9,8 & 38 \\
\hline Vieroitusikä, pv & 34 & 32 & 16 \\
\hline Kuoll.ennen vier, \% & 14 & 13 & 49 \\
\hline Tehottomuuspäiviä/pahnue, pv & 32 & 24 & 24 \\
\hline Vier. $\rightarrow$ tiineytykseen, pv & 9,3 & 8,0 & 68 \\
\hline Uusintatiineytyksiä, \% & 17 & 15 & 43 \\
\hline Porsimis-\% & 75 & 79 & \\
\hline Keskiemakkoluku, kpl & 75 & 68 & \\
\hline
\end{tabular}

Tuottajahintojen jyrkkä aleneminen vuoden 2002 aikana korosti porsastuotannon tehokkuuden merkitystä. Mitä enemmän tuotti porsaita, sitä paremmin pystyi sopeuttamaan toimintansa sikasyklin mukaan. Tilinpäätöstiloilla tuotettiin keskimäärin 18 porsasta emakkoa kohden vuodessa ja parhailla tiloilla 20. Porsaan tuotantokustannus nousi 73 euroon, kun se porsastuotantotiloilla vuonna 2001 oli 2 euroa alempi. Heikoin neljännes käyttää porsaan tuottamiseen 40 euroa enemmän kuin paras neljännes. Työtunteja kuluu paljon ja se maksaa. Yhteensä rehu- ja työkustannukset muodostavat $\mathrm{n}$. $70 \%$ kokonaiskustannuksista. Porsastuotannon tehokkuutta kuvaa hyvin tuotetun porsaan rehukustannus, joka parhaalla neljänneksellä on 9 euroa alempi kuin heikoimmalla neljänneksellä.

Sikatilinpäätöksen tulosten läpikäynnissä on tärkeä miettiä, mihin kustannuksiin pystyy itse vaikuttamaan ja miten paljon. Tunnusluvuista tuotto kertoo, paljonko porsaita tai lihasikoja on myyty ja minkälaista hintaa niistä on saatu. Tuottaja pystyy vaikuttamaan tuotettujen porsaiden määrään enemmän kuin hintaan. Tukien osuus on $16 \%$ tuotoista. Rehut muodostavat sikalassa suurimman menoerän. Rehukustannus lasketaan emakkoa kohden ja se kertoo, paljonko porsaiden ja emakoiden syömiin rehuihin kuluu rahaa. Kun rehukustannus jaetaan tuotettujen porsaiden määrällä, kertoo se tuotannon tehokkuudesta. Mitä alempi rehukustannus porsasta kohden on, sitä paremmin on rehustuksessa onnistuttu. Kun käydään tarkemmin läpi muuttuvia kustannuksia, linkittyy mukaan porsastuotannon seuranta. Tuotostuloksista voidaan osoittaa, että porsaskuolleisuudessa ja uusinnoissa on "paljon rahaa kiinni". Tehottomuuspäivät voidaan helposti muuttaa tilakohtaisesti euroiksi. Keskimäärin tehottomuuspäivän hinnaksi on laskettu 4,30 euroa/pahnue. Mikäli 100 emakon tilalla 
tehottomuuspäiviä/pahnue kertyy 12 päivää enemmän kuin parhailla tiloilla, menetetään katteessa 5161 euroa. On siis selvitettävä, mistä tehottomuuspäiviä muodostuu ja mihin tekijöihin voi itse vaikuttaa.

Vuonna 2002 jäi emakkoa kohden katetta 828 euroa. Katetuotto kertoo, paljonko rahaa jää oman työn ja palkkatyön kattamiseksi sekä poistoille ja koroille. Työkustannusten vähennysten jälkeen saadaan katetuotto II, josta vähennetään kone-, rakennus- ja yleiskustannukset. Jää jäljelle voitto, jolloin kaikki kustannukset on saatu katettua tai tappio, mikäli tuotto ei ole riittänyt kustannusten kattamiseen. Porsaan tuotantokustannus kertoo, paljonko porsaan tuottaminen on tilalla maksanut ilman tukea. Kun tuet huomioidaan, saadaan porsaan nettotuotantokustannus. Kannattavuuskerroin kuvaa sikalan kannattavuutta. Kannattavuuskerroin 1 kertoo, että omalle työlle on saatu täysi korvaus (12,10 euroa/tunti) ja sijoitetulle pääomalle on kertynyt korkoa 5\%.

Taulukko 2. Sikatilinpäätöstilojen porsaan tuotantokustannukset 2002. Ryhmittely porsaan tuotantokustannuksen mukaan. Sikatilinpäätös laskettiin 144 sikatilalle.

\begin{tabular}{|l|c|c|c|}
\hline & Keskiarvo & Paras 25\% & Heikoin 25\% \\
\hline Tuotot yhteensä, eur/em & 1502 & 1653 & 1310 \\
\hline Rehukustannus, eur/em & 447 & 433 & 439 \\
\hline Muut muuttuvat kust., eur/em & 182 & 169 & 210 \\
\hline Oma työ, eur/em & 425 & 347 & 550 \\
\hline Palkkatyö, eur/em & 27 & 28 & 130 \\
\hline Kone-, rak.ja yl.kust, eur/em & 168 & 151 & 1379 \\
\hline Kustannukset yht. Eur/em & 1294 & 1171 & 94 \\
\hline Tuotantokustannus/porsas & 73 & 43 & 19 \\
\hline Nettotuotantokustannus/porsas & 59 & 14 & 47 \\
\hline Tukien osuus tuotoista, \% & 16 & 29 & 9 \\
\hline Oma työ, tuntia/em & 36 & 29 & 214 \\
\hline Työansio/tunti, eur & 17 & 211 & 30 \\
\hline Rehun hinta/1000 ry, eur & 214 & 21 & \\
\hline Rehukust./tuotettu porsas, eur & 26 & 54 & \\
\hline
\end{tabular}

\section{Johtopäätökset}

Sikalan kannattavuutta ja tehokkuutta ei voida tarkastella pelkkinä lukuina. Jotta hyviin tuloksiin päästään, pitää koko sikalan tuotanto käydä kohta kohdalta läpi. Kun kehittämiskohteita mietitään, on ensin tiedettävä, missä kohtaa tuotantokiertoa syntyy eniten tehottomuutta ja tartuttava näiden asioiden parantamiseen. Kun onnistuu muita paremmin, lisää se omaa motivaatiota. Jokaiselta sikatalousyrittäjältä löytyy tavoite, mikä tuotannon tason tulisi olla. Tavoitteet pitää asettaa omien voimavarojen mukaan ja niihin on sitouduttava. Vaikka muutokset sikasyklissä vaikuttavat sikatalouden kannattavuuteen nopeastikin, pitää toimintaa kyetä suunnittelemaan pitkällä aikavälillä.

Ero porsastuotannon tehokkuudessa parhaimpien ja heikoimpien tilojen välillä ei ole kaventunut. Tärkeimmäksi tekijäksi nousee yrittäjän motivaatio tehdä parastaan sekä hyvinä että huonoina aikoina. Kyky johtaa ja hallita toimintaa ovat avaintekijöitä, joilla yritystä viedään eteenpäin. Tavoitteet pitää asettaa omien voimavarojen mukaan ja niihin on sitouduttava. Keskiarvot ja neljännesluokittelut antavat pohjaa tavoitteiden asettamiselle ja helpottavat niihin pääsemistä.

\section{Kirjallisuus}

ProAgria Maaseutukeskusten Liitto \& MTT/Sikatalous. 2003. Seminaariesitelmä Sikatalouden tulosseminaarissa 12.6.2003. Porsastuotannon tehokkuusluvut saatavilla Internetissä: www.proagria.fi 